\title{
Batch and Continuous Biogas Fermentation of the Fresh Water Algae Chlorella vulgaris - Detailed Process Analysis
}

Timm Adamietz ${ }^{1}$, Wojciech Jurkowski ${ }^{1}$, Jan Adolph ${ }^{2}$ and Thomas Brück ${ }^{1 *}$

${ }^{1}$ Department of Chemistry, Technical University of Munich (TUM), Munich, Germany

${ }^{2}$ DABEC-Bioenergy Consulting, Reuningstr 13, Dresden, Germany

\begin{abstract}
As algae grow about 10 times faster than terrestrial plants and their cultivation does not compete with agricultural activity, there is an enhanced interest in using algae biomass as an advanced biogas substrate. While previous reports focus on the influence of biomass pre-treatment and on biogas yields, this study examines the biogas fermentation dynamics in detail. To generate technically relevant results and delineate a recommendation for commercial biogas producers, our experimental set-up utilized a normed industrial, continuous setup according to VDI 4630 combined with regular gas and digestate analysis. This particular setup is conventionally applied for standard substrate tests when industrial customers optimize their processes. Although batch pre-experiments indicate biogas yields of 537.9 IN kg-1 VS for dried Chlorella and 443.6 IN kg-1 VS for the fresh biomass with methane concentrations of $60.0 \% \mathrm{v} / \mathrm{V}$ and $61.1 \% \mathrm{v} / \mathrm{v}$ respectively, we could not maintain these values under technically relevant organic loading rates. From our data we can conclude, that the maximum loading rate for stable continuous fermentation of $\mathrm{C}$. vulgaris is between 1.0 and $1.5 \mathrm{~kg} \mathrm{VS} \mathrm{m}^{-3} \mathrm{~d}^{-1}$. The main reason for this problem was sluggish digestion of proteins. This situation could be deduced by the high ammonia concentration in the fermentation broth $\left(\sim 3 \mathrm{gl}^{-1}\right)$ as well as the high nitrogen $\left(8 \mathrm{~g} \mathrm{~kg}^{-1} \mathrm{FM}\right)$ and protein $(54 \%$ (w/w TS) content in the digestate. Furthermore desulfurization was required to alleviate the inhibition of methanogenesis, which was observed from $1700 \mathrm{ppm} \mathrm{H}_{2} \mathrm{~S}$ in the biogas. Although better fermentation efficiency might theoretically be possible by altering the fermentation conditions and adaptation of microorganisms, the degradation of proteins would ultimately lead to inhibitory ammonia nitrogen concentrations. Our cumulative data indicate that fermentation of $\mathrm{C}$. vulgaris as monosubstrate is problematic and not advisable The application of algae biomass as a co-substrate could a valuable addition to any agricultural plant biomass substrate, which has a high carbohydrate content and low protein content (i.e., hydrolyzed cereal straw). Not only will the proteins increase methane concentration, but also the captured trace elements would positively influence the fermentation and fertilizer quality, which adds additional value to biogas side-product streams.
\end{abstract}

Keywords: Algae; Biogas; Chlorella; Continuous; Digestate analysis; Gas analysis; Methane yield; Organic loading rate

\section{Introduction}

The finite availability of fossil resources for energy generation and the resulting effects of climate change drive the industrial development of renewable energy solutions. While solar, wind and waterpower can be harnessed using only mechanical engineering, production of first and second generation biofuels that are based on terrestrial plant material are associated with land use change, reduced biodiversity and competition with food production. Microalgae grow 10 times faster than terrestrial plants and their cultivation can be accomplished on non-arable land utilizing waste-, brackish- or seawater. Therefore, algae biomass production for biofuel generation does not compete with agricultural activity and is not associated with land use change. Moreover, as algae biomass production is associated with minimal land use of $2 \mathrm{~m}^{2} / \mathrm{GJ}$ (as compared to $258 \mathrm{~m}^{2} / \mathrm{GJ}$ for rapeseed oil), there is sufficient potential to significantly contribute to a global solution for a sustainable energy supply [1]. Microalgae of the genus Chlorella sp., are one of the most productive biomass producers even when cultivated in simple outdoor, open pond systems using municipal wastewater $[2,3]$. In this configuration the algae biomass is not only a potential source of bioenergy, but it additionally facilitates wastewater treatment by the uptake of nutrients, which would otherwise lead to an eutrophication of natural water reservoirs [4]. Using algae cultures instead of the competing Anamox [5], processes for wastewater treatment is also superior in the context of nutrient recycling, as nitrogen is chemically fixed in the biomass. In contrast to the conventional Anamox process, nitrogen in algae biomass is not oxidized and released into the atmosphere. To that end, High Rate Algae Ponds (HRAP) are a particularly successful approach, which affords water treatment at an even lower energy demand and land use than conventional wastewater systems [6]. Although the efficiencies are obviously higher in regions with consistent sunlight, an experimental pilot plant of this kind is currently operating in Wessex (UK) with good results [7].

The immense interest and development in the field of algal biofuels as seen by the rising amount of related publications [8] has reached a point, where techno-economic studies confirm the feasibility of bioenergy generation based on wastewater utilization [9]. At present, most approaches for valorisation of algal biomass rely on their high lipid content and biodiesel production [8]. Nevertheless, the downstream processing of biomass including lipid extraction and transesterification is complex and energy demanding [10]. Novel approaches like hydrogen generation or hydrothermal liquefactionalthough promising-need further research and development to meet economic constraints [11]. In this context, an established and scalable

*Corresponding author: Brück T, Werner Siemens Chair of Synthetic Biotechnology, Department of Chemistry, Technical University of Munich, Lichtenberg Str. 4, 85748 Garching Near Munich, Germany, Tel: +498928913253; E-mail: brueck@tum.de

Received September 13, 2018; Accepted October 03, 2018; Published October 09, 2018

Citation: Adamietz T, Jurkowski W, Adolph J, Brück T (2018) Batch and Continuous Biogas Fermentation of the Fresh Water Algae Chlorella vulgaris - Detailed Process Analysis. J Bioprocess Biotech 8: 338. doi:10.4172/2155-9821.1000338

Copyright: ( 2018 Adamietz T, et al. This is an open-access article distributed under the terms of the Creative Commons Attribution License, which permits unrestricted use, distribution, and reproduction in any medium, provided the original author and source are credited. 
technology, namely biogas fermentation, is becoming a focal interest in the algae biotechnology community, due to its process robustness and scaling flexibility. As technological simplicity, process robustness and low investment costs are of primary concern for commercial operators, direct biogas production from the algal biomass, without the need for dewatering is a straightforward route for energy production. Raw algal biomass provides only between $15-84 \mathrm{~g} / \mathrm{l}$ dry matter making it inefficient in terms of organic loading rates and land use, therefore a pre-concentration step like cost efficient flocculation and potentially subsequent drying is advisable [12]. Considering excess heat production in many biogas cogeneration units an air-drying of the algal sediment prior to fermentation would also be feasible to enhance energy efficiency and reduce costs.

This study provides a thorough systematic assessment of biogas productivity in terms of total and space time yields using the freshwater algae Chlorella vulgaris as a feedstock. More importantly, we contrast the biogas performance of fresh and dried algae biomass samples in batch and continuous fermentation settings. Although algae cultivated in wastewater may just serve as co-substrate for existing biogas plants, their low dry matter discourages long distance transports. Utilization as a mono-substrate in dedicated plants may sometimes be the only economical solution, which is why we analyze the process stability and yields in this scenario. In this study we provide a detailed process analysis and potential optimization for algae biomass use in commercial biogas production scenarios.

\section{Materials and Methods}

\section{Batch fermentation of Chlorella vulgaris fresh and dried biomass}

Dry as well as fresh biomass was obtained from Roquette Klötze $\mathrm{GmbH}$ and Co. KG and had a total solids (TS) content of $8,8 \% \mathrm{w} / \mathrm{w}$ (fresh), and $88.5 \% \mathrm{w} / \mathrm{w}$ (dried) (Table 1 ). The volatile solids (VS) were $93.1 \mathrm{~g} \mathrm{gTS}^{-1}$ and $89.7 \mathrm{~g} \mathrm{gTS}^{-1}$ respectively. The data was estimated by airdrying the biomass for $24 \mathrm{~h}$ in an oven at $105^{\circ} \mathrm{C}$ (TS) and by combusting the dried sample in a muffle furnace at $550^{\circ} \mathrm{C}$ for $3 \mathrm{~h}$. This data was used to load the fermenters with similar VS amounts, which resulted in the following composition of each kind of batch experiment:

As reference microcrystalline cellulose (Avicel) of analytical grade, supplied by Sigma-Aldrich (Germany) was digested in order to confirm the correct project setup.

The fermentation has been conducted according to the VDI 4630 protocol to estimate the biogas yield at $38.0 \pm 0.5^{\circ} \mathrm{C}$ in a volume of 1.400 $\mathrm{ml}$ filled to 21 glass flasks. The generated biogas was measured with a gas flow meter (MilliGascounter, manufactured by Ritter, Germany). The gas composition comprising methane, carbon dioxide, oxygen, hydrogen and hydrogen sulfide was determined using a gas analyzer AwiFLEX (Awite, Germany).

\section{Continuous fermentation of Chlorella vulgaris fresh and dried biomass}

The experiment was conducted using three batches of fresh Chlorella vulgaris biomass supplied by Roquette Klötze $\mathrm{GmbH}$ and Co. KG. The biomass analysis prior to fermentation was performed as described (2.1). Resulting data is summarized in Table 2, in order to calculate the organic loading rate (OLR). All batches were delivered at the beginning and were kept sealed in a cool and dark place.

The continuous fermentation was performed for 64 days in $30 \mathrm{~L}$ glass fermenters $(\mathrm{H}=100 \mathrm{~cm} ; \mathrm{D}=20 \mathrm{~cm})$ equipped with central stirring, gas outlet, probing valve, temperature sensor and a spiral water heatexchanger. Each fermenter was inoculated with $28 \mathrm{~L}$ fermentation broth from an agricultural biogas plant. One liter digestate was removed manually every day, while the fermenter was agitated. Subsequently, the digestate was mixed with fresh biomass and recirculated as feed to adjust for volume changes in the reaction vessel. Once a week the fill level of the fermenter was adjusted by removing digestate for sampling. During the fermentation organic loading rates (OLR) have been increased in 0.5 steps from $1.0-3.0 \mathrm{~kg} \mathrm{VS} \mathrm{m}^{-3} \mathrm{~d}^{-1}$ each time when the biogas production had stabilized. The temperature was held constant at $42.0 \pm 0.3^{\circ} \mathrm{C}$, and the agitator was working in 10 minute intervals followed by 5 minute pause rates. The gas composition and amount was measured using the same devices as described in paragraph 2.1, with the exception, that gas flows above $1 \mathrm{~L} \mathrm{~h}^{-1}$ were measured with a drum type gas meter TG 0.5 (Ritter, Germany).

The resulting digestate was analysed on a weekly basis. For this purpose, samples were collected $5 \mathrm{~h}$ after feeding for the first 40 days and then 2 hours after feeding, due to the measured low volatile

\begin{tabular}{|c|c|c|c|}
\hline Experiment & Blank & Reference & Chlorella dry \\
\hline Substrate & None & Cellulose & Dry algae biomass \\
\hline Inoculum input Mean (g FM/Batch) & 1400 & 792 & 790 \\
\hline Water input Mean (g/Batch) & 0 & 610 & 610 \\
\hline Substrate input Mean (g FM/Batch) & 0 & 11 & 14 \\
\hline pH Value at start & 7.8 & 7.9 & 7.1 \\
\hline Fermentation time (d) & 28 & 28 & 28 \\
\hline
\end{tabular}

Table 1: Composition for batch fermentation experiments.

\begin{tabular}{|c|c|c|}
\hline & Batch 1 & Batch 2 \\
\hline TS (\%) & 11.0 & 13.4 \\
\hline VS (\%TS) & 93.8 & 92.0 \\
\hline VS (\% FM) & 10.3 & 12.4 \\
\hline pH & 5.3 & 12.9 \\
\hline
\end{tabular}

Table 2: Characteristics of the biomass batches used for the continuous fermentation, where: FM: fresh biomass 
organic acid content. Total solids (TS) and volatile solids (VS) were estimated (see 2.1). Additionally, volatile organic acids (VOA) were measured by gas chromatography (CP-3800 GC, Varian Analytical Instruments, USA). Total inorganic carbon (TIC) was measured by oxidation and IR-detection with (TOCOR 2, manufactured by Maihac, Germany). Furthermore, ammonia nitrogen $\left(\mathrm{NH}_{4}-\mathrm{N}\right)$ was measured using a salicylate-based ammonia-nitrogen kit (supplied by Hach Lange, Germany) and a spectrophotometer (Hewlett-Packard 8453 UV-Vis PAD, Germany). After terminating the fermentation process, the digestate was additionally analysed for heavy and trace metals by inductively coupled plasma optical emission spectroscopy (ICP-OES 710 Series manufactured by Agilent Technologies, USA), as well as proximities (after Weende).

In order to supress excessive hydrogen sulphide release one gram of desulfurizing agent Bayoxide E33 (LANXESS, Germany) was added daily, beginning from day 59 .

\section{Calculations}

The cumulative gas amounts (both methane and biogas) have been corrected to normal liters (at 273, $15 \mathrm{~K}$ and $101325 \mathrm{P}$, according to DIN 1343) according to equation 1

$$
\begin{array}{lll}
\multicolumn{2}{c}{V_{N}=V * \frac{\left(\mathrm{p}_{a}-p_{w}\right) * T_{N}}{p_{N} * T} \ldots \ldots \ldots \ldots \ldots . . . . . .} \\
\text { Where, } \mathrm{V}_{\mathrm{N}} & (\mathrm{l}) \quad \text { normal volume of gas, } \\
\mathrm{V} & (\mathrm{l}) \quad \text { produced gas volume, } \\
\mathrm{p}_{\mathrm{a}} & (\mathrm{Pa}) \quad \text { atmospheric pressure at gas measurement time, } \\
\mathrm{p}_{\mathrm{w}} & (\mathrm{Pa}) & \text { vapor pressure of water, } \\
\mathrm{T}_{\mathrm{N}} & (\mathrm{K}) & \text { normal temperature: } 273.15 \mathrm{~K}, \\
\mathrm{~T} & (\mathrm{~K}) & \text { Gas temperature. }
\end{array}
$$

Furthermore, the concentrations of methane and carbon dioxide have been adjusted to account for $100 \%$ of biogas (according to VDI 4630) according to the following equation:

$$
\begin{aligned}
& C_{\mathrm{CO}_{2}}=C^{\text {mes }}{ }_{\mathrm{CO}_{2}} * \frac{100}{C^{\text {mes }}{ }_{\mathrm{CO}_{2}}+C^{\text {mes }}{ }_{\mathrm{CH}_{4}}} \\
& C_{\mathrm{CH}_{4}}=C^{\text {mes }}{ }_{\mathrm{CH}_{4}} * \frac{100}{C^{\text {mes }} \mathrm{CO}_{2}+C^{\text {mes }} \mathrm{CH}_{4}}
\end{aligned}
$$

Where, $\mathrm{C}_{\mathrm{CO}_{2}}(\% \mathrm{v} / \mathrm{v}) \quad$ corrected carbon dioxide concentration,

$\mathrm{C}_{\mathrm{CH}_{2}}^{\text {mes }}(\% \mathrm{v} / \mathrm{v})$ corrected methane concentration,

$\mathrm{C}^{\text {mes }} \mathrm{CH}_{2}(\% \mathrm{v} / \mathrm{v})$ measured carbon dioxide concentration,

$\mathrm{C}^{\text {mes }} \mathrm{CH}_{4}(\% \mathrm{v} / \mathrm{v})$ measured methane concentration.

The required amount of fresh biomass used to feed the fermenter was calculated according to its content of organic solids:

$$
\text { Feed }\left[g * d^{-1}\right]=\frac{O L R * V_{F}}{T S_{S} * V S_{S}} \ldots \ldots \ldots \ldots \ldots
$$

Where, OLR $\left(\mathrm{kg} \mathrm{m}^{-3} \mathrm{VS} \mathrm{d}^{-1}\right) \quad$ Organic Loading Rate,

$$
\begin{array}{lll}
\mathrm{V}_{\mathrm{F}} & \left(\mathrm{m}^{3}\right) & \text { Fermenter volume, } \\
\mathrm{TS}_{\mathrm{S}} & (\% \mathrm{w} / \mathrm{w}) & \text { Total solids content of Substrate, } \\
\mathrm{VS}_{\mathrm{S}} & (\% \mathrm{w} / \mathrm{w}) & \text { Volatile solids content of substrate. }
\end{array}
$$

\section{Results and Discussion}

\section{Batch fermentation of fresh and dried Chlorella vulgaris biomass}

The reference sample reached $785.51 \mathrm{~N} \mathrm{~kg}^{-1}$ VS biogas yield, which confirmed the validity of the experiment, as the calculated value according to VDI 4630 is $745 \mathrm{lN} \mathrm{kg}^{-1} \mathrm{VS} \pm 10 \%$. For both fresh and dry algae biomass, $90 \%$ of total biogas was produced after 18 days fermentation (Figure 1). The biogas yield of the samples was $537.9 \mathrm{lN}$ $\mathrm{kg}^{-1} \mathrm{VS}$ for dried Chlorella biomass and $443.6 \mathrm{lN} \mathrm{kg}^{-1} \mathrm{VS}$ for the fresh biomass with methane concentrations of $60.0 \%(\mathrm{v} / \mathrm{v})$ and $61.1 \%(\mathrm{v} / \mathrm{v})$ respectively (Figure 2). Therefore, the total methane yield of fresh $C$. vulgaris was significantly lower with $270.9 \mathrm{lN} \mathrm{kg}^{-1} \mathrm{VS}$ than it was the case for the dried biomass, which reached $322.6 \mathrm{lN} \mathrm{kg}^{-1} \mathrm{VS}$, as was depicted in Figure 3. This might be due to cell-disrupting properties of the drying process, which led to a release of some otherwise inaccessible nutrients, such as intracellular fats and proteins. To that end, the intracellular protein yield, this for Chlorella biomass can be as high as $60 \%$ of cell dry weight, may have been the predominant factor in enhanced biogas production from dried biomass. These findings are however in contrast to the literature, where drying of algae was reported to decrease the biogas yield to about $80 \%$ of the reference for the similar Chlorella kessleri. The authors had however measured only $3351 \mathrm{~N} \mathrm{~kg}^{-1}$ VS of biogas in their experiment. Another group reported biogas yields of $459 \mathrm{lN} \mathrm{kg}^{-1} \mathrm{VS}$ for fresh, untreated Chlorella sp. Biomass [13], which is very similar to our results.

In this study we could demonstrate, that dried Chlorella can generate similar methane yields as maize silage, which yields between 300 and $3501 \mathrm{~N} \mathrm{~kg}^{-1}$ VS depending on the cultivar and harvesting time [14].

Interestingly, the our fresh algae biomass fermented more stable, reaching a maximum biogas production rate at day four followed by a rapid yield decline (Figure 1). By contrast, the dried biomass started to ferment more vigorously producing about $50 \%$ more biogas on the first day, compared to the fresh substrate. However, thereafter a decreased productivity was observed. This effect might also be explained with the higher accessibility of nutrients, such as proteins or simple sugars, which upon hydration immediately dissolve in the fermentation broth, without the need of complex hydrolysis. When this reservoir was depleted, the residual dry biomass requires additional time for the full hydration of components necessary for adsorption of

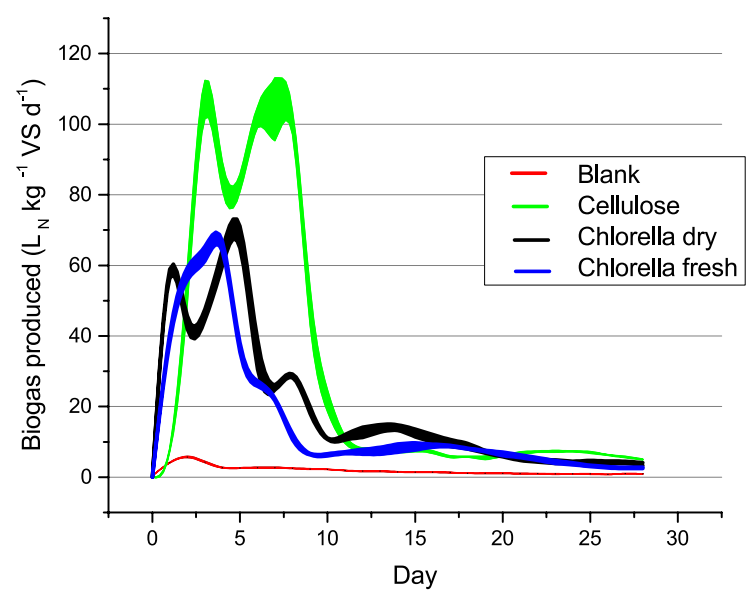

Figure 1: Daily biogas production during batch fermentation of $C$. vulgaris. Mean from 3 samples. Line thickness represents standard deviation. 


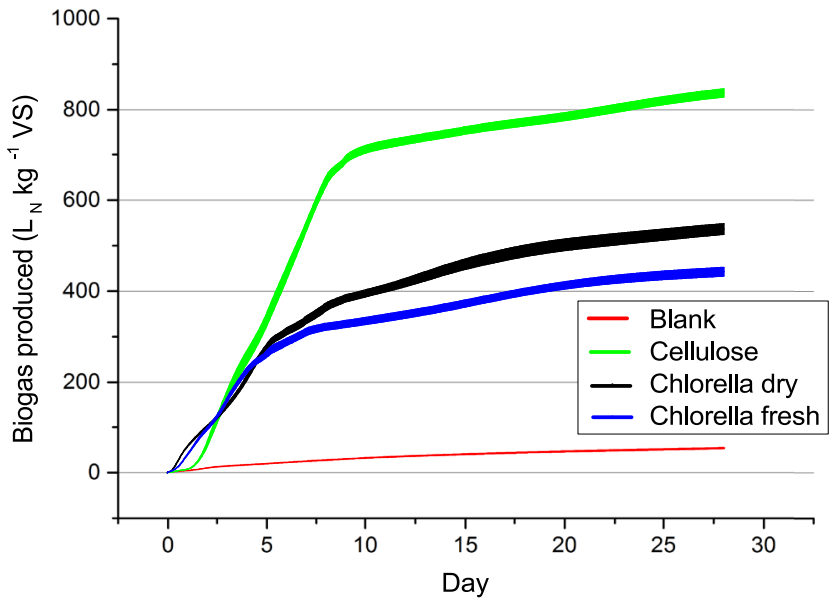

Figure 2: Cumulative biogas production during batch fermentation of $C$. vulgaris Mean from 3 samples. Line thickness represents standard deviation.

enzymes, which enable subsequent depolymerisation of carbohydrate polymers (i.e., amorphous cellulose, hemicellulose) and proteins into fermentable components such as amino acids and monomeric sugars. In consequence, this scenario delays the fermentation process. An analogous fermentation pattern can be observed with cellulose, which also is a dry carbohydrate polymer substrate. With the applied cellulose sample, the carbohydrate degree of polymerization and crystallinity is even higher than in dried algae cell walls. Therefore, an extended time period was required to enzymatically generate fermentable monomeric sugars (glucose), which translates into an even longer lag phase preceding significant biogas yields.

\section{Continuous fermentation of Chlorella vulgaris fresh and dried biomass}

Initially, the fermentation was stable, as indicated by a low VOA/TIC ratio reaching 0.25 at the time, when the experiment was terminated after 64 days with an OLR of $3.0 \mathrm{~kg} \mathrm{VS} \mathrm{m}^{-3} \mathrm{~d}^{-1}$ (Figure 4) Subsequently, new batches of algae biomass were introduced at day 16 , and 52 . The second batch led to an approximately $25 \%$ decrease in daily biogas production, which slowly regenerated within the next 7 days. This effect however, can be also attributed to the increase of the loading rate, which occurred 3 days previously. The introduction of the third batch did not significantly influence the fermentation in any respect.

At a loading rate of one $\mathrm{kg} \mathrm{VS} \mathrm{m}^{-3} \mathrm{~d}^{-1}$, the specific biogas yield was approximately $500 \mathrm{lN} \mathrm{kg}^{-1} \mathrm{VS} \mathrm{d}^{-1}$, which accounts for $94 \%$ or $114 \%$ of the biogas yield achieved in the batch experiment with dried and fresh Chlorella respectively. At this point, the hydraulic retention time in the fermenter with about 103 days was far longer than in the batch experiment. According to the results of the batch experiment the required time for $90 \%$ biogas yield was only 18 days, hence the loading rate could have been even 5 times higher. In practice, the stepwise increase was followed by a significant decrease of the biogas yield as shown in Tables 3 and 4 (Figures 5 and 6). Interestingly it is evident, that with increasing fermentation time the methane concentration increased up to day 50 from $57 \% \mathrm{v} / \mathrm{v}$ to $63 \% \mathrm{v} / \mathrm{v}$ meaning that more fats $(70 \% \mathrm{v} / \mathrm{v}$ methane) or proteins $(75 \% \mathrm{v} / \mathrm{v}$ methane) were hydrolyzed and converted to methane. Another possibility is the accumulation of micronutrients in the fermenter, as the analysis of digestate after the terminated fermentation process (Table 5) shows unusually high concentrations of heavy and trace elements. While this is not unexpected, because microalgae have a tendency for metal uptake from the environment [15], the consequences on the biogas yield and methane concentration might be immense and are usually positive in the measured concentration range [16].

The decline of the methane concentration observed from day 51 might originates from a small fermentation instability, which is also reflected in the much higher amount of organic acids (VOA/TIC at 0.23 as compared to 0.13 during the previous measurements). This event might be a consequence of high hydrogen sulfide concentrations (over 1700 ppm, see Figure 7) leading to an inhibition of methanogensis and accumulation of undigested hydrolysis products.

Both the total solids as well as volatile solids (Figure 6) have started to steadily cumulate since day 25 and reached $7,8 \% \mathrm{w} / \mathrm{w}$ and $82 \% \mathrm{w} / \mathrm{w}$ respectively by the end of fermentation. The tendency of decreasing fermentation efficiency is also reflected in the biogas yield, which dropped from 506.8 in $1 \mathrm{~N} \mathrm{~kg}^{-1} \mathrm{VS} \mathrm{d}^{-1}$ at the start of the experiment to

\begin{tabular}{|c|c|c|c|c|}
\hline Experiment & Blank & Reference & Chlorella dry & Chlorella fresh \\
\hline Substrate & None & Cellulose microcrystalline & Dry algae biomass & Fresh algae biomass \\
\hline Specific gas yield $1 \mathrm{~N} \mathrm{~kg} \mathrm{FM}$ & $1.9 \pm 0.1$ & $776.5 \pm 10.4$ & $463.4 \pm 12.6$ & $52.1 \pm 1.4$ \\
\hline Specific gas yield IN kg VS & $53.8 \pm 2.1$ & $823.5 \pm 11.1$ & $537.9 \pm 14$ & $443.6 \pm 12.1$ \\
\hline Specific methane yield IN kg VS & 26.6 & 423.1 & 322.6 & 270.9 \\
\hline Mean methane content $\%$ & 49.4 & 50.5 & 60 & 61.6 \\
\hline Mean carbon dioxide content \% & 22.1 & 47.0 & 37.7 & 37.7 \\
\hline $\mathrm{pH}$ after fermentation & 7.7 & 7.7 & 7.7 & 7.5 \\
\hline
\end{tabular}

Table 3: Results of batch fermentation experiments.

\begin{tabular}{|c|c|c|c|c|c|c|c|c|c|}
\hline Fermentation time (d) & 7 & 14 & 21 & 28 & 35 & 42 & 49 & 56 & 63 \\
\hline TS (\% FM) & 5.7 & 6.0 & 5.6 & 6.1 & 6.5 & 6.6 & 6.7 & 6.9 & 7.8 \\
\hline VS (\% TS) & 73.0 & 73.9 & 74.0 & 76.8 & 78.0 & 79.6 & 80.5 & 82.0 & 82.4 \\
\hline VOA/TIC & 0.13 & 0.17 & 0.14 & 0.19 & 0.13 & 0.13 & 0.23 & 0.20 & 0.25 \\
\hline $\mathrm{pH}$ & 7.6 & 7.8 & 7.8 & 7.8 & 7.8 & 7.9 & 7.8 & 7.8 & 7.8 \\
\hline $\mathrm{NH}_{4}-\mathrm{N}(\mathrm{mg} / \mathrm{l})$ & 2970 & 2700 & 2910 & 2920 & 3110 & 3180 & 3210 & 3490 & 3460 \\
\hline $\mathrm{C}_{2}-\mathrm{C}_{6}(\mathrm{mg} / \mathrm{l})$ & $<20$ & & $<20$ & & $<20$ & & $<20$ & & $<20$ \\
\hline Acetic acid (mg/l) & 170 & - & 120 & - & 430 & - & 660 & - & 590 \\
\hline $\begin{array}{l}\text { Sampling time (h after } \\
\text { feed) }\end{array}$ & 5 & 5 & 5 & 5 & 2 & 2 & 2 & 2 & 2 \\
\hline
\end{tabular}

Table 4: Overview of the digestate analysis from continuous fermentation of $C$. vulgaris. 
340 in $1 \mathrm{~N} \mathrm{~kg}^{-1} \mathrm{VS} \mathrm{d}^{-1}$ at the end of the fermentation.

The ammonia nitrogen content was high, yet not in the range of inhibition. However, the total nitrogen of $8.0 \mathrm{~g} \mathrm{~kg}^{-1}$ indicates, that still high amounts were bound in the organic matter. The proximate analysis presented in Table 6 confirms this assumption, showing that $54.3 \%$ $\mathrm{w} / \mathrm{w}$ of the digestate solid substance consists of nitrogen containing proteins which have not been degraded yet. Lipids and polysaccharides have been degraded fairly well with $3.6 \% \mathrm{w} / \mathrm{w}$ and $9.5 \% \mathrm{w} / \mathrm{w}$ remaining in the digestate respectively. Numerous literature reports demonstrate, that Chlorella can produce $>50 \% \mathrm{w} /$ dry cell weight of protein if cultivated under non-limiting conditions [17]. According to our data this protein is not easily degradable in a biogas plant, leading to relatively a low biogas yield. On the other hand, if the remaining proteins were digested, the amount of dissolved nitrogen content might have risen above the inhibition level of $3.5 \mathrm{~g} \mathrm{l}^{-1}$ [18]. This would have caused problems with the fermentation. It is likely, that non hydrolyzed proteins accumulated over the entire fermentation period, since the concentration of dissolved nitrogen did not significantly increase with increased loading rate. While the biogas production at the end of the fermentation was almost double $\left(28.61 \mathrm{~N} \mathrm{~d}^{-1}\right)$ as compared to the start of the experiment $\left(14.6 \mathrm{lN} \mathrm{d}^{-1}\right)$, the ammonium-nitrogen had increased from $2970 \mathrm{mg} \mathrm{l}^{-1}$ to only $3460 \mathrm{mg} \mathrm{l}^{-1}$, indicating that no more proteins were hydrolyzed to amino acids, which could have been metabolized by the microbial biogas consortium.

The hydrogen sulfide concentration in the biogas (Figure 7) was low in the first 10 days and started to steadily increase up to day 40, when unexpectedly a strong decrease was observed. This correlated with the increase of the feeding rate from 2.0 to $2.5 \mathrm{~kg} \mathrm{VS} \mathrm{m}^{-3}$, which induced a significant increase of the specific biogas yield. After this temporary event, the concentration returned to its previous level of approx. 1700 ppm within the next 5 days. The addition of the desulfurizing agent reduced this concentration from day 59 to below $800 \mathrm{ppm}$. This in turn led to a slow but steady increase of the specific biogas yield in the final days of fermentation. In this context, it is worth mentioning, that $\mathrm{H}_{2} \mathrm{~S}$ is a degradation product of sulfur containing amino acids, such as methionine and cysteine. Its elevated concentration clearly indicates the slightly increased digestion of proteins, subsequently leading to higher methane concentrations [19].

\section{Conclusions}

We have investigated the biogas fermentation of Chlorella vulgarisone of the main industrially available microalgae species. Our initial batch fermentation experiments have demonstrated relatively high biogas yields of up to $537.9 \mathrm{IN} \mathrm{kg}^{-1} \mathrm{VS}$ for dried chlorella and $443.6 \mathrm{lN}$ $\mathrm{kg}^{-1} \mathrm{VS}$ for the fresh biomass with methane concentrations of $60.0 \%$ $\mathrm{v} / \mathrm{v}$ and $61.1 \% \mathrm{v} / \mathrm{v}$ respectively. While these initial data were promising, these biogas yields could not be reproduced in a commercially relevant continuous fermentation setting. Our results demonstrate that utilization of Chlorella biomass as mono-substrate is problematic, due to its high protein content. A seemingly stable fermentation has led to a severe accumulation of unfermented organic matter, which resulted in $54 \%$ protein by dry weight in the digestate. With the applied process setting, it was impossible to maintain reasonable biogas yields at elevated biomass concentrations. Particularly, at loading rates above $2.0 \mathrm{~kg} \mathrm{VS} \mathrm{m}^{-3} \mathrm{~d}^{-1}$ the biogas yield dropped to under $400 \mathrm{lN} \mathrm{kg}^{-1} \mathrm{VS} \mathrm{d}^{-1}$. Simultaneously, volatile solids in the fermenter started to accumulate at $1.5 \mathrm{~kg} \mathrm{VS} \mathrm{m}^{-3} \mathrm{~d}^{-1}$ and reached $82 \% \mathrm{w} / \mathrm{w}$ of total solids at the end of the experiment. Based on our cumulative data, we conclude, that the maximum loading rate for continuous fermentation of $\mathrm{C}$. vulgaris

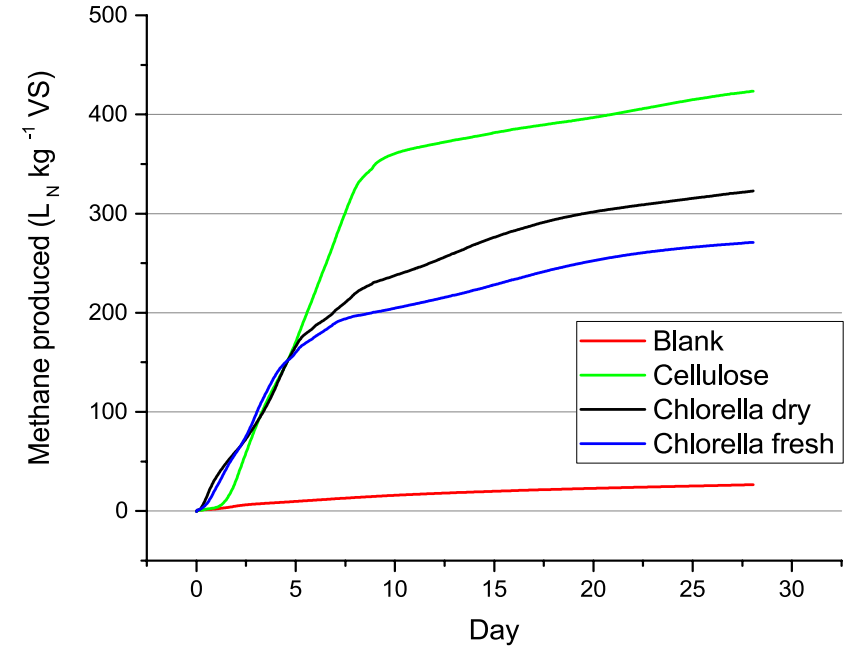

Figure 3: Cumulative methane production during batch fermentation of $C$. vulgaris. Mean from 3 samples.

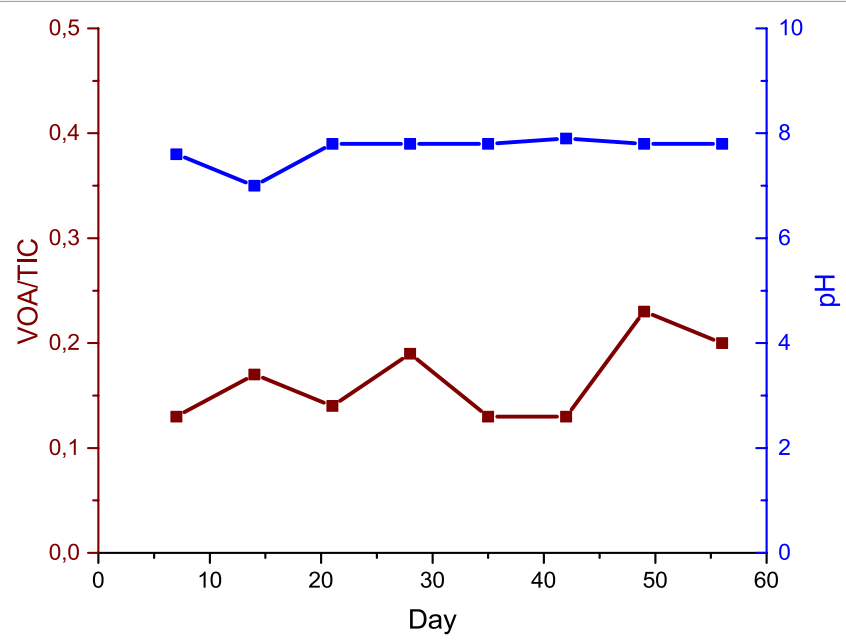

Figure 4: $\mathrm{pH}$ value and VOA/TIC during continuous fermentation of $C$. vulgaris

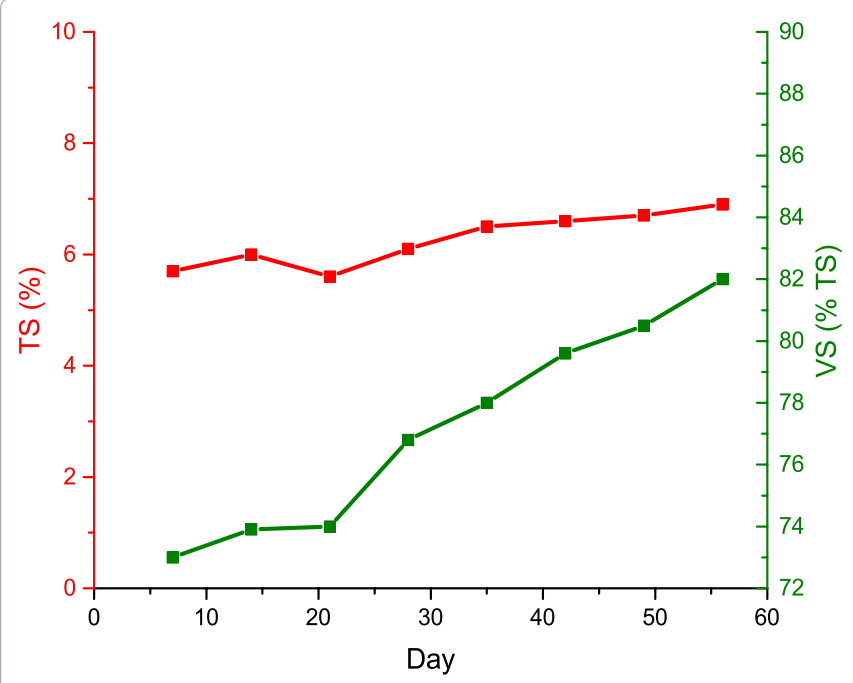

Figure 5: TS and VS during continuous fermentation of $C$. vulgaris. 


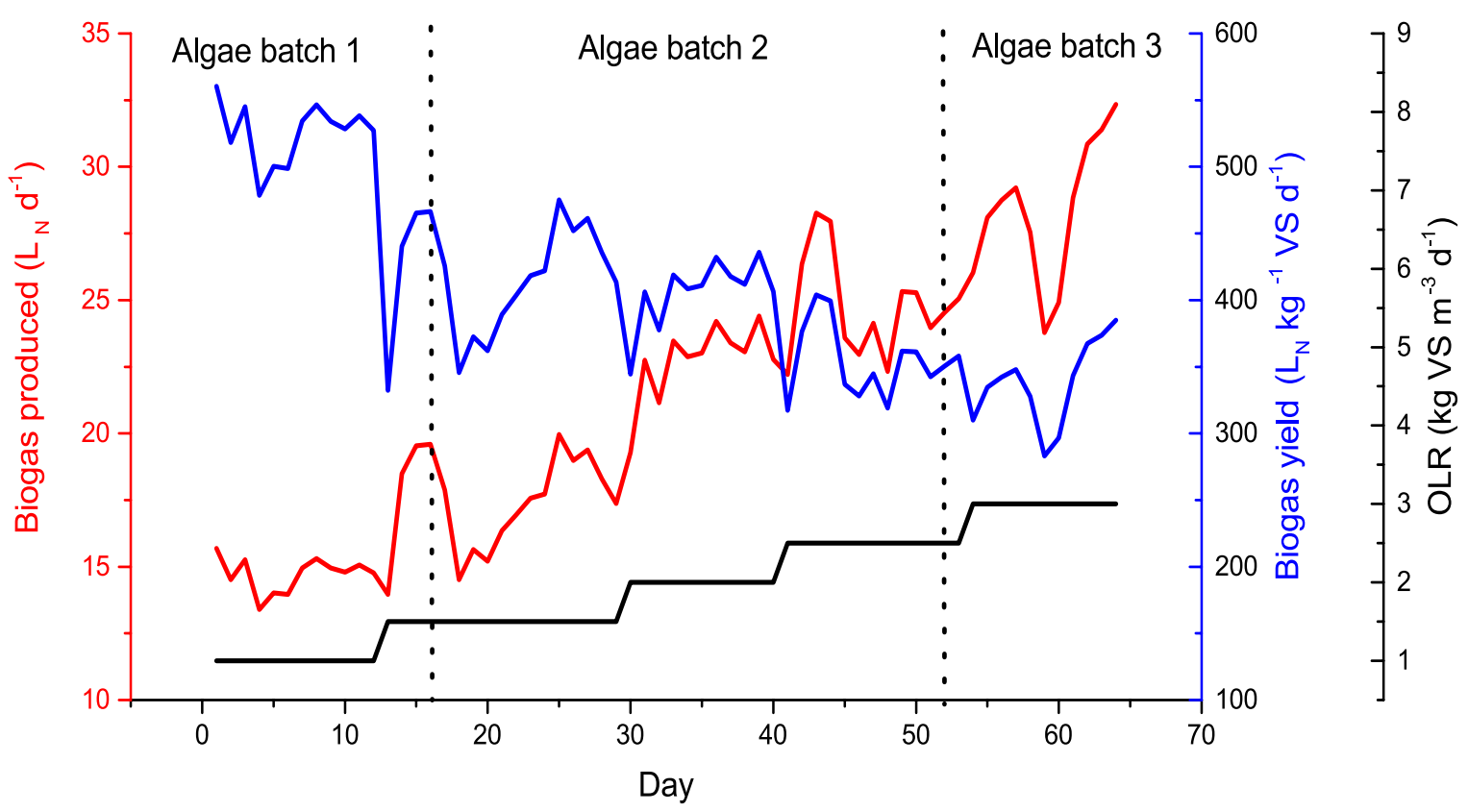

Figure 6: Daily biogas production and biogas yield during continuous fermentation of $C$. vulgaris.

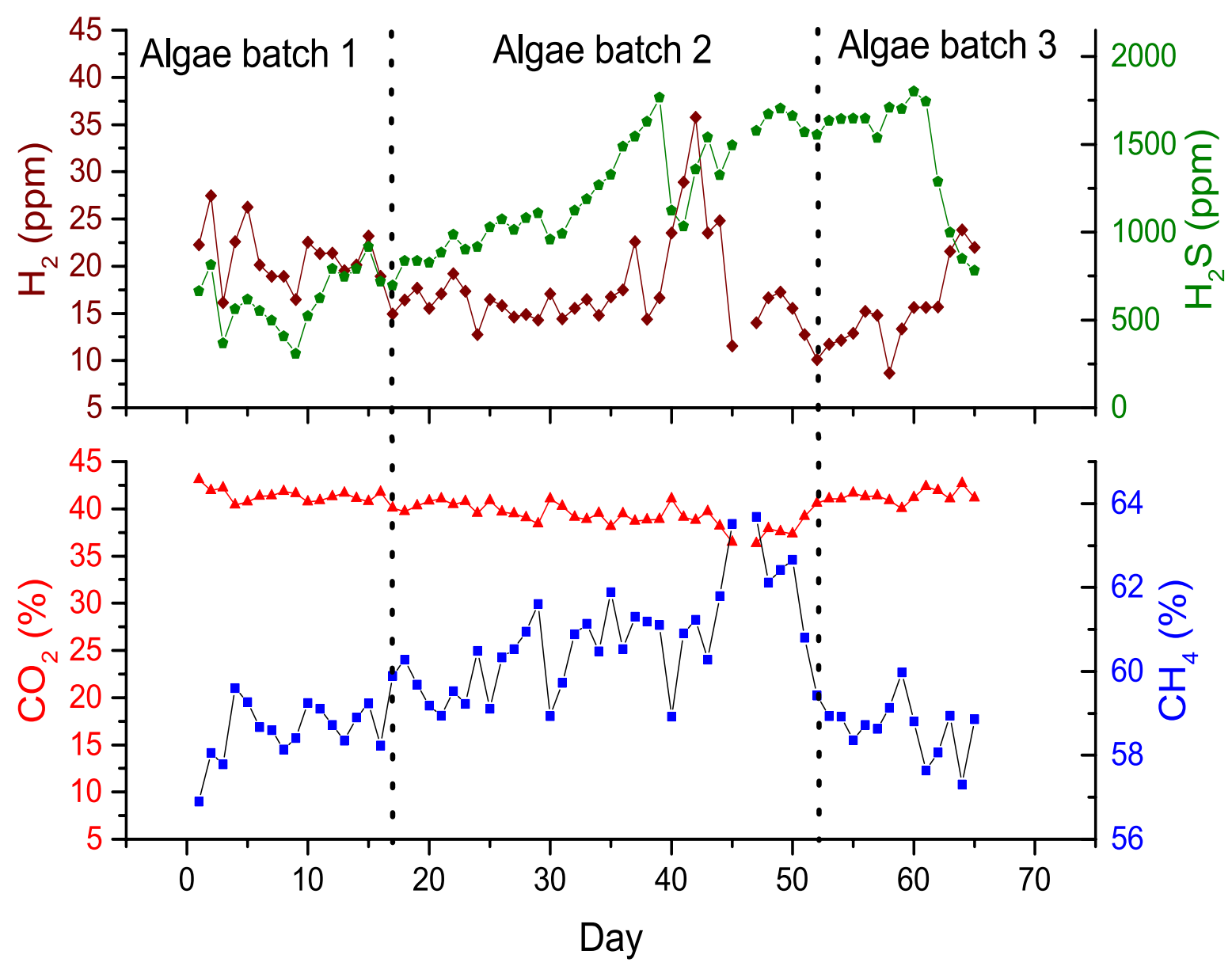

Figure 7: Biogas composition during continuous fermentation of $C$. vulgaris. 
Citation: Adamietz T, Jurkowski W, Adolph J, Brück T (2018) Batch and Continuous Biogas Fermentation of the Fresh Water Algae Chlorella vulgaris - Detailed Process Analysis. J Bioprocess Biotech 8: 338. doi:10.4172/2155-9821.1000338

Page 7 of 8

\begin{tabular}{|c|c|c|c|}
\hline Day of fermentation & Organic loading rate (OLR) (kg VS $\left.\mathrm{m}^{-3} \mathrm{~d}\right)$ & Mean biogas production (IN d) & Mean biogas yield (IN kg VS d-1) \\
\hline $1-13$ & 1.0 & $14.6 \pm 0.6$ & $506.8 \pm 58.7$ \\
\hline $13-29$ & 1.5 & $17.8 \pm 1.6$ & $417.2 \pm 42.3$ \\
\hline $29-40$ & 2.0 & $23 \pm 0.9$ & $404 \pm 32.5$ \\
\hline $41-53$ & 2.5 & $25.1 \pm 1.8$ & $353.2 \pm 28.2$ \\
\hline $54-64$ & 3.0 & $28.6 \pm 2.7$ & $340.2 \pm 32.1$ \\
\hline
\end{tabular}

Table 5: Mean biogas production from continuous fermentation of $C$. vulgaris by OLR.

\begin{tabular}{|c|c|c|c|c|c|c|c|}
\hline $\mathrm{Pb}$ mg kg TS & Cd mg kg TS & As mg kg TS & Cr mg kg TS & Cu mg kg TS & Ni mg kg TS & Zn mg kg TS & Mn mg kg TS \\
\hline 14 & $<0.26$ & $<3.9$ & 26 & 560 & 22 & 300 & 210 \\
\hline Se mg kg TS & Fe mg kg TS & Co $\mathrm{mg} \mathrm{kg}^{-1} \mathrm{TS}$ & $\mathrm{B} \mathrm{mg} \mathrm{kg}{ }^{-1} \mathrm{TS}$ & Mo $\mathrm{mg} \mathrm{kg}^{-1} \mathrm{TS}$ & $\mathrm{Hg} \mathrm{mg} \mathrm{kg}^{-1} \mathrm{TS}$ & $\mathrm{N}$ tot $\mathrm{g} \mathrm{kg}^{-1} \mathrm{FM}$ & $\mathrm{NH}_{4}-\mathrm{N} \mathrm{g} \mathrm{kg}^{-1} \mathrm{FM}$ \\
\hline$<0.32$ & 2500 & 9.3 & 26 & $<0.65$ & $<0.04$ & 8 & 3.11 \\
\hline $\mathrm{P} \mathrm{g} \mathrm{kg}^{-1} \mathrm{FM}$ & $\mathrm{P}_{2} \mathrm{O}_{5} \mathrm{~g} \mathrm{~kg}^{-1} \mathrm{FM}$ & $\mathrm{Kg} \mathrm{kg}^{-1} \mathrm{FM}$ & $\mathrm{K}_{2} \mathrm{O} \mathrm{g} \mathrm{kg}{ }^{-1} \mathrm{FM}$ & $\mathrm{Mg} \mathrm{g} \mathrm{kg}^{-1} \mathrm{FM}$ & $\mathrm{MgO} \mathrm{g} \mathrm{kg}^{-1} \mathrm{FM}$ & Ca g kg-1 FM & $\mathrm{CaO} \mathrm{g} \mathrm{kg}^{-1} \mathrm{FM}$ \\
\hline 2.4 & 5.5 & 2.8 & 3.4 & 0.5 & 0.8 & 0.9 & 1.3 \\
\hline $\mathrm{Na} \mathrm{g} \mathrm{kg}{ }^{-1} \mathrm{FM}$ & $\mathrm{S} \mathrm{g} \mathrm{kg}^{-1} \mathrm{FM}$ & Ash \%TS & Protein \%TS & Fiber \%TS & Fat $\%$ TS & & \\
\hline 0.3 & 0.33 & 18.3 & 54.3 & 9.5 & 3.6 & & \\
\hline
\end{tabular}

Table 6: Digestate analysis after finished continuous fermentation of $C$. vulgaris.

was between 1.0 and $1.5 \mathrm{~kg} \mathrm{VS} \mathrm{m}^{-3} \mathrm{~d}^{-1}$, however this quantity may be strongly dependent on bioreactor geometry and pretreatment, as well as potential adaptation of microorganisms over extended time periods. The biogas contained approx. $1700 \mathrm{ppm} \mathrm{H}_{2} \mathrm{~S}$ and required desulfurization to overcome inhibition. Although ammonium nitrogen was low, an otherwise welcome increase of substrate degradation rate would raise its concentration above the inhibition limit. In summary, we would not advise a biogas plant operator to ferment C. vulgaris as mono-substrate but use it in combination with protein poor, carbohydrate rich substrates such as cereal straw. As the latter predominantly consists of cellulose and hemicellulose polymers, it has to be enzymatically hydrolyzed prior to fermentation to release fermentable sugars. In combination, the protein rich algae biomass would be a valuable addition to any agricultural plant, based on carbohydrates. In that regard, algae derived proteins will increase methane concentration and capture trace elements, which would positively impact the fermentation and resulting digestate fertilizer quality, thereby increasing the value to this biogas side-stream. In that regard, the combination of algae biomass with hydrolyzed agricultural residues, such as cereal straw or wood chips, represent an advanced biogas substrate admixture with an optimal $\mathrm{C} / \mathrm{N}$ ratio, which does not compete with agricultural food production. Hence, the combination of algae biomass and agricultural waste streams for biogas production is in line with governmental targets that increasingly impose legislative and economic barriers on conventional biogas substrates, such as maize silage. It is therefore recommended, that commercial biogas producers may start to include algae biomass cultivated on waste water (or other non-fresh water resources) and non-arable land in their substrate portfolio.

\section{References}

1. Singh A, Nigam PS, Murphy JD (2011) Renewable fuels from algae: An answer to debatable land based fuels. Bioresour Technol 102: 10-16.

2. Kothari R, Pathak VV, Kumar V, Singh DP (2012) Experimental study for growth potential of unicellular alga Chlorella pyrenoidosa on dairy waste water: An integrated approach for treatment and biofuel production. Bioresour Technol 116: 466-470.

3. Wang L, Min M, Li Y, Chen P, Chen Y, et al. (2010) Cultivation of green algae Chlorella $\mathrm{sp}$. in different wastewaters from municipal wastewater treatment plant. Appl Biochem Biotechnol 162: 1174-1186

4. Rawat I, Ranjith Kumar R, Mutanda T, Bux F (2011) Dual role of microalgae: Phycoremediation of domestic wastewater and biomass production for sustainable biofuels production. Applied Energy 88: 3411-3424.

5. Cao Y, van Loosdrecht MCM, Daigger GT (2017) Mainstream partial nitritationanammox in municipal wastewater treatment: Status, bottlenecks, and further studies. Applied Microbiology and Biotechnology 101: 1365-1383.

6. Young P, Taylor M, Fallowfield HJ (2017) Mini-review: High rate algal ponds, flexible systems for sustainable wastewater treatment. World Journal of Microbiology and Biotechnology 33: 117.

7. Tunnicliffe H (2017) Wessex Water and Bath trial algae treatment. The Chemical Engineer.

8. Azadi P, Malina R, Barrett SRH, Kraft M (2017) The evolution of the biofuel science. Renewable and Sustainable Energy Reviews 76: 1479-1484.

9. Xin C, Addy MM, Zhao J, Cheng Y, Cheng S, et al. (2016) Comprehensive techno-economic analysis of wastewater-based algal biofuel production: A case study. Bioresour Technol 211: 584-593.

10. Mubarak M, Shaija A, Suchithra TV (2015) A review on the extraction of lipid from microalgae for biodiesel production. Algal Research 7: 117-123.

11. Chiaramonti D, Prussi M, Buffi M, Rizzo AM, Pari L (2017) Review and experimental study on pyrolysis and hydrothermal liquefaction of microalgae for biofuel production. Applied Energy 185: 963-972.

12. Mussgnug JH, Klassen V, Schlüter A, Kruse O (2010) Microalgae as substrates for fermentative biogas production in a combined biorefinery concept. J Biotechnol 150: 51-56

13. Bohutskyi P, Betenbaugh MJ, Bouwer EJ (2014) The effects of alternative pretreatment strategies on anaerobic digestion and methane production from different algal strains. Bioresour Technol 155: 366-372.

14. Eder B, Eder J, Papst C, Darnhofer B, Mukengele M, et al. (2009) Welcher Maissortentyp zur Biogaserzeugung. International Science Conference Biogas Science 1: 57-72.

15. Fraile A, Penche S, González F, Blázquez ML, Muñoz JA, Ballester A (2005) Biosorption of copper, zinc, cadmium and nickel by Chlorella vulgaris. Chem Ecol 21: 61-75.

16. Piorreck M, Baasch KH, Pohl P (1984) Biomass production, total protein chlorophylls, lipids and fatty acids of freshwater green and blue-green algae under different nitrogen regimes. Phytochem 23: 207-216. 
Citation: Adamietz T, Jurkowski W, Adolph J, Brück T (2018) Batch and Continuous Biogas Fermentation of the Fresh Water Algae Chlorella vulgaris - Detailed Process Analysis. J Bioprocess Biotech 8: 338. doi:10.4172/2155-9821.1000338

Page 8 of 8

17. Demirel B, Scherer P (2011) Trace element requirements of agricultural biogas digesters during biological conversion of renewable biomass to methane. Biomass and Bioenergy 35: 992-998.
18. FNR (2016) Leitfaden Biogas - Von der Gewinnung zur Nutzung.

19. Sánchez Hernández EP, Travieso Córdoba L (1993) Anaerobic digestion of Chlorella vulgaris for energy production. Resources, Conservation and Recycling 9: 127-132. 